\title{
Praktek Al-`Urf: Istinbat Hukum Dalam Transaksi Ekonomi Kontemporer
}

\author{
Muh. Fudhail Rahman \\ Fak. Syariah dan Hukum \\ UIN Syarif Hidayatullah Jakarta
}

\begin{abstract}
Abstrak
Praktek ekonomi saat ini seakan tidak ada kata henti untuk terus menerus dikembangkan. Baik dalam ranah wacana, regulasi serta pemahaman dalam mindset kaum muslimin dan masyarakat. Salah satunya adalah kebiasaan dan tradisi yang terkait dengan praktek akad dan produk ekonomi syariah, yang dikenal dengan 'urf atau adat. Tulisan berikut memarparkan tentang bahasan urf dan adat dari aspek defenisi, wacana yang diperdebatkan oleh para ulama dan cendekiawan, hingga pada implementasi dalam kehidupan saat ini. Metode yang digunakan dalam tulisan berikut adalah deskriptif analisis. Tulisan ini mendukung dan menguatkan bahwa kajian 'urf dan adat dalam wacana istibath hukum Islam, termasuk dalam kajian perkembangan ekonomi syariah memiliki peran yang tidak bisa diabaikan. Kedua sumber hukum Islam legal dan absah sebagai salah satu metode memutuskan hukum Islam.
\end{abstract}

\section{A. Pendahuluan}

Untuk memahami syari'at Islam yang diemban Rasulullah Saw, para ulama ushûl fiqh mengemukakan dua bentuk pendekatan, yaitu melalui kaidahkaidah kebahasaan dan melalui kaidah-kaidah maqâshid al-syari'ah (tujuan-tujuan syara' dalam menetapkan hukum).

Pendekatan melalui kaidah-kaidah kebahasaan adalah untuk mengetahui dalil-dalil yang khas, muthlaq dan muqayyad, mujmal dan mubayyan, muhkam, mufassar, mutasyabih, nash, zhahir, nasikh mansukh, amr nahiy dan sebagainya. Dalam kaidah-kaidah kebahasaan ini dikemukakan cara-cara menyelesaikan dalil-dali yang bertentangan secara zahir, sehingga seluruh dalil yang ada dalam al-Qur'an dan Sunnah dapat dipahami serta diamalkan. Persoalan hukum dalam pendekatan ini terkait langsung dengan nash (al-Qur'an atau Sunnah).

Pendekatan maqâshid al-syari'ah, penekanannya terletak pada upaya menyingkap dan menjelaskan hukum dari suatu kasus yang dihadapi melalui pertimbangan maksud-maksud syara' dalam menetapkan hukum. Teori yang digunakan untuk menyingkap dan menjelaskan hukum dalam berbagai kasus 


\section{SALAM; Jurnal Sosial \& Budaya Syar-i}

FSH UIN Syarif Hidayatullah Jakarta

Vol. 6 No. 4 (2019)

yang tidak ada nash (ayat atau hadis) secara khusus, dapat diketahui melalui metode ijma', qiyas, istihsan,, istishlah, sadd zari'ah, 'urf dll. Hakekat maqâshid alsyari'ah adalah kemashlahatan manusia di dunia dan akhirat. Oleh karena itu, dalam mengungkap dan menjelaskan suatu kasus hukum yang tidak ada nashnya, hendaknya selalu berorientasi pada kemashalatan umat.

Secara khusus, dalam tulisan ini mencoba menyingkap bahasan metode al-'urf - atau al-'adat dalam istilah ulama fiqh namun esensinya sama- secara metodoligis dan aplikatif, serta dikaitkan dengan praktek dan kajian ekonomi syariah.

\section{B. Pengertian 'Urf atau Adat}

Kata 'urf dan adat berasal dari bahasa Arab. Kata adat sudah diserap ke dalam bahasa Indonesia dengan pengertian yang sama dalam bahasa Arab, yaitu kebiasaan atau praktek. Pada dasarnya, 'urf atau adat memiliki akar kata dan pengertian etimologi yang berbeda, meskipun secara terminology dipandang sama.

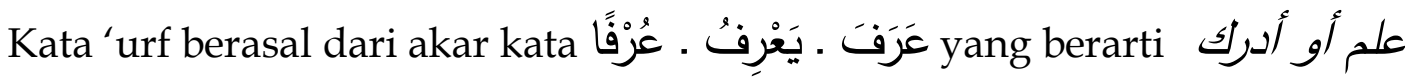
atau mengetahui dan mengenal. ${ }^{1}$ Sedangkan adat berasal dari akar kata . عَادَ yang berarti وَعْوْدُ . عَوْدَةً yَاصَلَ atau memulai baru dan mengulangi.2 Bisa juga berarti وَمُعَاوَدَةُ وَتِكْرَارُ وَالْجَمَاعِيَهُ yang berarti pembiasaan atau pengulangan serta berjama'ah. ${ }^{3}$ Musthafa Ahmad al-Zarqâ4 mengatakan bahwa 'urf berarti ma'rifah, "sesuatu yang sudah dikenal", kemudian kata tersebut digunakan dalam pengertian :

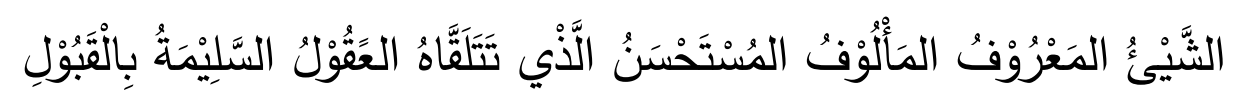

"Sesuatu yang dikenal, disukai, yang dianggap baik dan diterima oleh akal sehat".

Pengertian tersebut sebagaimana dalam kitab suci al-Qur'an :

1 Atabik Ali dan Ahmad Zuhdi Muhtadhar, Kamus Kontemporer : Arab Indonesia, Yogyakarta: Yayasan Ali Maksum Pondok Pesantren Krapyak. H. 1283.

2 Atabik Ali dan Ahmad Zuhdi Muhtadhar, Kamus Kontemporer, ... h. 1257.

${ }^{3}$ Muhammad bin Mukrâm bin Mandzûr al-Afrîqî al-Mishrî, Lisân al-'Arab, Beirut: Dar Shâdr, Jil. 3, Cet. 1. H. 315. Lihat juga Ibnu 'Abidîn dalam risalahnya II/114, sebagaimana dikutip dan disepakati oleh Wahbah Zuhailî, Ushûl al-Fiqh al-Islâmî, Damaskus: Dâr al-Fikr,jilid 2, 1996. h. 828. Lihat juga, Amir Syarifuddin, Ushûl Fiqh, Jakarta: Logos Wacana Ilmu dan Pemikiran, Jilid 2, 2001. H. 363.

4 Musthafâ Ahmad al-Zarqâ, Al-Madkhal al-Fiqh al-'Am, juz I. Damaskus : Dâr al-Fikr, 1967-8. H. 130-1. 


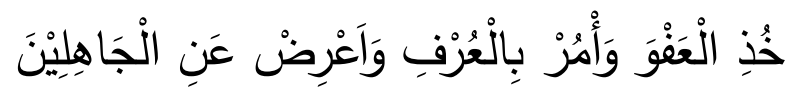

"Jadilah Engkau Pema' af dan suruhlah orang mengerjakan yang ma' ruf".

Sedangkan menurut terminology, 'urf sama dengan 'adat dan ta'amul, yaitu:

$$
\text { عَادَةُ جُمْهُهْرِ فِي قَوْلِ أَوْ عَمَلِ }
$$

"Adat atau kebiasaan mayoritas kaum, baik dalam ucapan maupun perbuatan".

Defenisi tersebut menurut zarqâ disarikan dari beberapa defenisi 'urf dan adat dari sejumlah fuqaha, yang dikemukakan oleh Ibnu Abidin dalam risalahnya.

Sejalan dengan pengertian 'urf, yaitu sesuatu yang dikenal baik, Amir Syarifuddin berpendapat bahwa ada perbedaan antara 'urf dan adat, yaitu 'urf memiliki konotasi perbuatan yang dikenal baik dan diterima oleh akal sehat. Sedangkan adat tidak memiliki konotasi perbuatan yang baik, adat bersifat netral, dan meliputi perbuatan baik dan buruk. Namun, pada akhirnya, tampak ada transisi, 'urf disamakan dengan adat. ${ }^{5}$ 'Urf lebih dikenal dalam kajian ushul fikih, sedangkan adat dikenal dalam kajian qawa'id fikihiyah. Dalam pengertian lain, 'urf yang secara etimologi berarti dikenal lebih dominan kepada makna sesuatu yang seudah dikenal masyarakat, berlaku umum di antara mereka. Sedangkan adat lebih condong kepada makna terus menerus atau berulangulang (istimrâr). Namun, kedua istilah ini, esensinya sama, baik 'urf dalam bentuk ucapan maupun perbuatan.

Lebih lanjut beda antara 'urf dan adat, bisa dilihat pada table berikut:

Tabel 1. Tabel perbandingan antara 'Urf dengan 'Adah'

\begin{tabular}{|l|l|}
\hline \multicolumn{1}{|c|}{ 'Urf } & \multicolumn{1}{|c|}{ 'Adah } \\
\hline $\begin{array}{l}\text { Adat memiliki makna yang lebih } \\
\text { sempit }\end{array}$ & $\begin{array}{l}\text { Adat memiliki cakupan makna yang } \\
\text { lebih luas }\end{array}$ \\
\hline Terdiri dari 'urf shahih dan fasid & $\begin{array}{l}\text { Adat tanpa melihat apakah baik atau } \\
\text { buruk }\end{array}$ \\
\hline $\begin{array}{l}\text { 'Urf merupakan kebiasaan orang } \\
\text { banyak }\end{array}$ & Adat mencakup kebiasaan pribadi \\
\hline & Adat juga muncul dari sebab alami \\
\hline & $\begin{array}{l}\text { Adat juga bisa muncul dari hawa } \\
\text { nafsu dan kerusakan akhlak }\end{array}$ \\
\hline
\end{tabular}

${ }^{5}$ Amir Syarifuddin, Ushûl Fiqh,... h. 364.

6 http://informationmedia.wordpress.com/2009/04/15/al-\%E2\%80\%98urf-sebagaisalah-satu-metode-ushul-fiqih-dalam-meng-istimbath-setiap-permasalahan-dalam-kehidupan 
Kebanyakan ahli ushul fiqh menyamakan 'urf dan adat. Mereka mengemukakan defenisi yang secara garis besar menunjuk pada pengertian yang sama. Di antara defenisi itu adalah sebagai berikut :

1. Wahbah Zuhailî, mendefenisikan 'urf sebagai berikut :

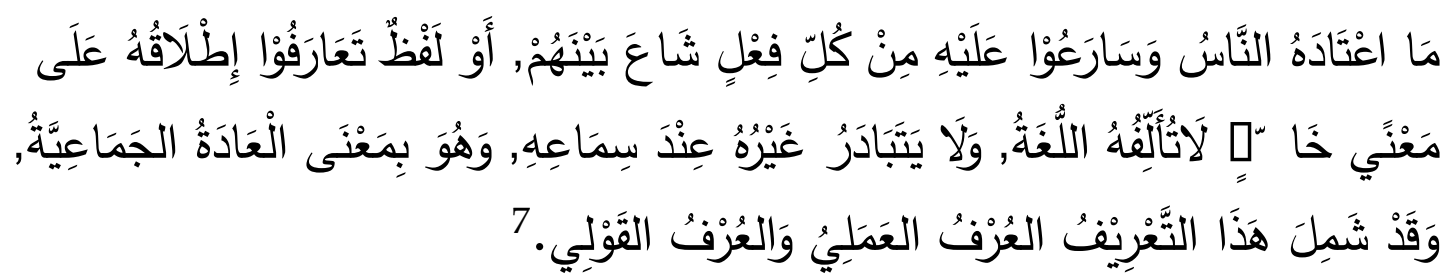

"Urf adalah suatu perbuatan yang menjadi kebiasaan manusia, dan sangat dikenal di tengah-tengah masyarakat, atau perkataan yang bentuk lughawianya mutlak namun pengertiannya khusus menurut adat. Sehingga, pengertian khusus itulah yang bisa dipahami secara cepat. Pengertian 'urf'ini sama dengan adat masyarakat dan meliputi perbuatan maupun perkataan (fi'lî dan qaulî).

2. Ahmad Fahmî Abû Sinnah, sebagai berikut :

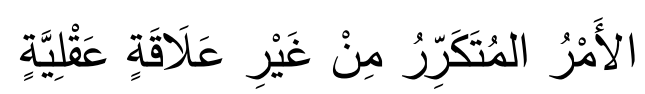

Perbuatan-perbuatan yang telah sering dilakukan tanpa melalui pertimbangan rasional.

3. Muhammad Abu Zahrah, sebagai berikut :

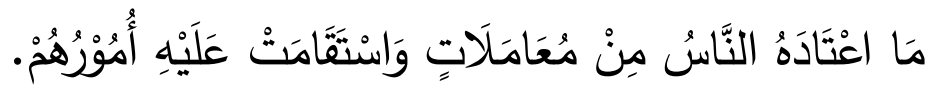

Segala bentuk mu'amalah yang telah dikenal manusia serta konsisten menjalankannya.

Dari beberapa pengertian di atas, bahwasanya 'urf atau adat merupakan kebiasaan atau tradisi yang berulang-ulang dilakukan, masyhur, dalam keabsahannya telah disepakati dan tidak ada pertimbangan rasio sehingga tingkat penerimaan masyarakat penggunanyapun sangat tinggi.

\section{Penyerapan Adat pada masa Rasulullah dan Sahabat}

Tidak dapat diragukan bahwa masyarakat Arab sebelum kerasulan Muhammad Saw telah memiliki adat yang digunakan untuk mengatur kehidupan mereka. Adat tersebut tidak dihapus sepanjang sesuai dengan prinsip-prinsip ajaran Islam yang dibawa oleh Muhammad. Bahkan Nabi Muhammad dalam kapasitasnya sebagai pembuat hukum dari sebuah agama yang baru, memberikan tempat bagi praktek hukum adat dalam system hukum Islam yang baru. ${ }^{8}$ Nabi Muhammad memberi sentuhan inovatif terhadap adat,

7 Wahbah Zuhailî, ... h. 828.

${ }^{8}$ Wali Allah al-Dihlâwî, Hujjatullah al-Bâlighâ, Kairo: Dâr al-Turats, Vol. 1, 1185 H. h. 124125. 
tanpa merubah secara radikal system yang sudah lama berjalan tersebut ke dalam suatu bentuk yang baru. Bahkan lebih dari itu, banyak bagian-bagian dari system lama tersebut masih tetap hidup dan menjadi bagian dari system hukum Islam yang baru. ${ }^{9}$

Dengan demikian, dapat disimpulkan bahwa banyak cabang dari hukum Islam dipenuhi oleh peraturan-peraturan yang keputusan hukumnya ditetapkan oleh Nabi berdasar pada adat kebiasaan yang berlaku. Misal dari aturan-aturan tersebut dapat ditemukan hampir di setiap aspek hukum.

Dalam hal hukum pidana, misalnya kita melihat bahwa keseluruhan hukum qisas dan pembayaran diyât diadopsi dari praktek masyarakat Arab pra Islam. ${ }^{10}$ Perubahan utama yang dilakukan oleh Nabi adalah memasukkan prinsip keseimbangan ${ }^{11}$ kedalam kerangka hukum qisas. Namun, ide utama dan prinsip-prinsip yang mendasarinya tidaklah bersifat baru dan telah dipraktekkan jauh sebelum lahirnya Islam. Dalam hukum Islam, satu jiwa harus diambil karena perbuatan menghilangkan jiwa orang lain atau pemberian kompensasi harus dilakukan terhadap keluarga korban. Aturan ini tidak mempersoalkan status suku atau kedudukan si korban dalam sukunya, sebagaimana adat sebelum Islam.

Dalam bidang hukum keluarga, Nabi mempertahankan beberapa praktek hukum yang telah lama diketahui oleh masyarakat Arab sebelum Islam dengan memodifikasi dengan prinsip-prinsip hukum yang masuk akal dan landasan moral yang baik. Rasul menghapuskan beberapa praktek yang telah secara luas dilakukan oleh bangsa Arab, seperti praktek poliandri, hubungan seksual yang tidak sah, ${ }^{12}$ pembunuhan terhadap bayi perempuan, adopsi, perceraian yang berulang-ulang dan lain sebagainya. Sementara itu, Rasul tetap mempertahankan dengan memberi modifikasi terhadap praktek pemberian mahar, ${ }^{13}$ pemberitahuan dalam hal perkawinan (iqrar) poligami dan waris.

Bentuk transaksi komersial pra Islam yang tidak bertentangan dengan prinsip-prinsip Islam tetap dipertahankan dan dimasukkan ke dalam system hukum Islam. ${ }^{14}$ Seperti system mudharabah, syuf'ah, salam dan lain-lain.

${ }^{9}$ Noel J. Coulsoun, The History of Islamic Law, Edinburgh University Press, 1964. H. 18-19

${ }^{10}$ Sayyid Sâbiq, Fiqh Sunnah, Kairo: Dâr al-Tsaqâfah al-Ilmiyyah, Jil. 2, t.t. h. 327.

11 Sayyid Sâbiq, Fiqh Sunnah...Lihat QS. Al-Mâidah (5): 45; “Dan kami Telah tetapkan terhadap mereka di dalamnya (At Taurat) bahwasanya jiwa (dibalas) dengan jiwa, mata dengan mata, hidung dengan hidung, telinga dengan telinga, gigi dengan gigi, dan luka luka (pun) ada kisasnya.

${ }^{12}$ Sayyid Sâbiq, Fiqh Sunnah... h. 5.

${ }^{13}$ Sayyid Sâbiq, Fiqh Sunnah... h. 101.

${ }^{14}$ Sayyid Sâbiq, Fiqh Sunnah... Jil. III. H. 147-156. 
Dari contoh-contoh di atas, dapat disimpulkan bahwa Nabi tidak menentang tradisi-tradisi masyarakat yang bersesuaian dengan misi dakwah yang ia emban. Dengan penerimaan adat yang disetujui oleh Nabi tersebut, problem-problem masyarakat bisa diatasi dengan keinginan masyarakat.

Praktek Rasul Saw tersebut dicontoh oleh para sahabatnya. Misalnya, khalifah Umar meneruskan praktek kaisar bizantium dalam mempertahankan system diwân, atau registrasi. Ia mendirikan lembaga ini antara lain untuk kepentingan tentara dan untuk urusan financial (al-mâliyah). Bahasa yang berasal dari daerah taklukkan tetap menjadi bahasa yang resmi digunakan pada masingmasing lembaga diwân tersebut, dan para pegawai yang menanganinya kebanyakan orang-orang Yunani dan Persia. Sebagaimana kenyataaan lembaga ini dalam masyarakat Islam mengindikasikan bahwa para sahabat tidak membatasi pengadopsian adat hanya pada adat kebiasaan yang terdapat dalam masyarakat mereka sendiri, melainkan juga menerima praktek adat kebiasaan yang berasal dari tradisi non-muslim. Terutama di beberapa propinsi sebelah timur, institusi-institusi masyarakat Sasanid, yaitu diwân al-kharâj dan diwân alnafaqât, juga dipertahankan di Irak sesudah masuknya daerah ini ke dalam wilayah Islam. ${ }^{15}$

\section{Adat dalam Pandangan Imam Mazhab Empat}

Abû Hanîfah, pendiri mazhab Hanafî, memasukkan adat sebagai salah satu fondasi pada prinsip Istihsan. Menurut Syarakhsî, ia menolak qiyâs untuk lebih berpegang pada 'urf. ${ }^{16}$ Sebagai contoh, Sarakhsî mengilustrasikan, seseorang yang membeli kayu sebanyak satu angkutan onta. Dalam hal ini, penjual bertanggung jawab menurut adat untuk mengantarkan kayu tersebut ke rumah pembeli.

Berdasar qiyâs, kondisi ini hanya akan berjalan jika disebutkan secara spesifik dalam kontrak pembelian. Namun, demikian jika adat yang dipraktekkan dalam masyarakat menentukan demikian, maka si penjual harus mengantarkan kayu tersebut sampai ke rumah pembeli tanpa harus ada dalam kontrak pembeliannya. Lebih lanjut, Sarakhsî mengabarkan bahwa Abu Hanîfah menginterpretasikan makna aktual dari suatu adat sesuai dengan makna yang secara umum dipakai dalam masyarakat, namun adat tersebut harus ditolak jika bertentangan dengan nash. ${ }^{17}$

15 Muhammad Musthafâ Syalabî, Ushûl al-Fiqh al-Islâmî, Beirut: Dâr al-Nahdhah al'Arabiyyah, Jilid I, 1986. H. 319.

16 Al-Sarakhsî, al-Mabsût, Kairo: mathba'ah al-Sa'adahl, 1324-1331, jilid 12. H. 199.

17 Al-Sarakhsî, al-Mabsût, $h .17$ 


\section{SALAM; Jurnal Sosial \& Budaya Syar-i}

FSH UIN Syarif Hidayatullah Jakarta

Vol. 6 No. 4 (2019)

Abû Yûsuf, salah seorang murid terkemuka Abu Hanîfah, mengatakan bahwa adat menjadi pertimbangan yang utama dalam mazhab Hanafî, terutama ketika nash yang jelas tidak dapat diketemukan. ${ }^{18}$ Muhammad Ibn Hasan alSyaibânî (w. 189 H), menjadi hakim agung pada pemerintahan Harun al-Rasyîd, senantiasa bertanya tentang adat dari berbagai macam bentuk perdagangan dan profesi sebelum mengeluarkan suatu fatwa yang berhubungan dengan praktekpraktek kerja profesional. ${ }^{19}$

Dalam hal mudharabah, biaya yang dibutuhkan untuk perjalanan bisnis dari seorang partner ditentukan berdasarkan adat. ${ }^{20}$ Al-Syaibânî mengemukakan beberapa aturan interpretasi yang teoritis yang menunjukkan kepentingan jurisprudensial dari adat. Ia menyebutkan beberapa kaidah hukum, yaitu $^{21}$ :

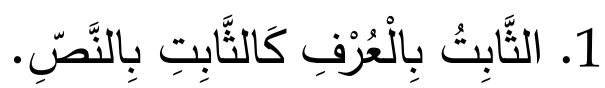

Ketetapan hukum sebagai derivasi dari adat sama dengan ketetapan hukum yang diambil dari nash.

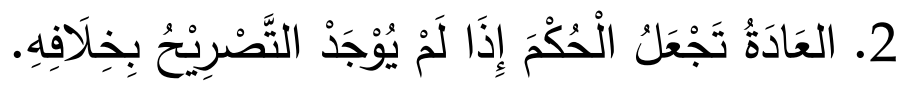

Adat menjadi hukum yang pasti jika tidak ada ketentuan lain yang menyalahi nash.

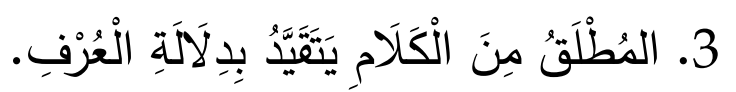

Ketetapan yang umum bisa dispesifikasikan dengan ketentuan dari adat.

$$
\text { 4. العَادَةُ مُعْتَبَرَةُ فِيْ تَقْيِيْدِ الكَلَامِ }
$$

Adat bersifat valid untuk memberi ketentuan yang bersifat umum.

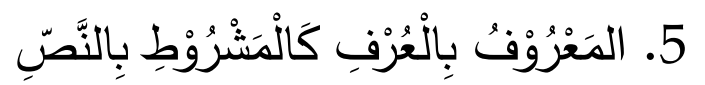

Pengetahuan yang bersumber dari 'urf, sama dengan persyaratan yang didasarkan oleh nash.

Imam Malik mengemukakan bahwa aturan-aturan adat dari satu negara harus dipertimbangkan dalam memformulasi suatu ketetapan, meskipun ia memandang, bahwa kebiasaan penduduk Madinah sebagai variabel yang paling otoritatif dalam teori hukumnya. ${ }^{22}$ Beliau juga memandang adat atau kebiasaan

18 Ibn al-Hummâm, Syarh Fath Qadîr, Kairo : Mathba'ah Musthafâ Muhammad, Jil. 5, 1356. H. 282.

${ }^{19}$ Muhammad Musthafâ Syalabî, Ushûl al-Fiqh al-Islâmî, h. 320.

${ }^{20}$ Muhammad Musthafâ Syalabî, Ushûl al-Fiqh al-Islâmî, h. 321.

21 Muhammad Ibn Hasan al-Syaibânî, Siyâr al-Kabîr, Jilid 1: 194-8. Sebagaimana yang dikutip dalam Muhammad Hamidullah, Muslim Condust of State, Lahore: S.h. Muhammad Asyraf, 1945. H. 34.

${ }^{22}$ Ahmad Hasan, Pintu Ijtihad Sebelum Tertutup, Bandung: Pustaka 1984. H. 92. 


\section{SALAM; Jurnal Sosial \& Budaya Syar-i}

FSH UIN Syarif Hidayatullah Jakarta

Vol. 6 No. 4 (2019)

masyarakat Madinah sebagai konsensus pendapat umum yang mencukupi untuk digunakan sebagai sumber hukum ketika tidak ada nash yang eksplisit. Bahkan kebiasaan penduduk Madinah dapat mengalahkan hadis ahad.23

Ahli hukum mazhab Mâlikîyah, al-Syâthibî (w. 790 H), berpendapat bahwa ada lokal yang tidak bertentangan dengan semangan Islam dapat menjadi penuntun untuk mengaplikasikan hukum. Ia membedakan antara dua macam adat atau kebiasaan: yang pertama ia sebut dengan "al-'awâid al-syar'iyah", yang terdiri atas tradisi-tradisi yang disetujui nash atau dalil syar'I lainnnya. Yang kedua; ia sebut "al-'awâid al-jâriyah", yang terdiri dari berbagai macam bentuk adat yang didiamkan oleh syari'ah dalam arti tidak menerima dan tidak menolak. Sementara, penerimaan syari'ah terhadap kelompok yang pertama tergantung kepada kesesuaiannya dengan syari'ah itu sendiri.

Kelompok yang kedua tidak bersifat mengikat dan dengan demikian bersifat mubah. ${ }^{24}$ Dalam kitab al-Muwâfaqât, al-Syathibî juga menyebutkan hubungan antara mashlahah dan 'urf, disamping membahas hubungannya dengan sumber-sumber hukum Islam lainnya. Sebagai doktrin yang bersifat inheren dengan tujuan-tujuan yang umum dari syari'ah, kepentingan umum dapat menjadi satu faktor dalam mengukur penerimaan adat. ${ }^{25}$ Dalam pandangan Syathibî, adat setempat yang tidak bertentangan dengan semangat Islam dapat menjadi penuntun dalam mengaplikasikan syari'ah dan juga dapat menjadi basis dari variasi lokal dalam aturan-aturan yang tidak bertentangan dengan masalah-masalah pribadi.

Imam Syafi'i dan Imam Ahmad ${ }^{26}$ tidak begitu memperhatikan adat dalam keputusan hukumnya. Hal ini dapat dilihat dari fakta bahwa dalam dua karya utamanya, al-Umm dan al-Risâlah, Imam Syafi'î tidak mendiskusikan peran adat sebagai sumber hukum. Bahkan beliau cenderung tidak mengakui tradisi sebagai suatu pertimbangan hukum dan menekankan pada hadis, walaupun hadis itu ahad. ${ }^{27}$ Namun begitu, adanya qaul jadid Syafi'i yang dikompilasikan setelah ia di Mesir, ketika dikontraskan dengan qaul qadimnya di Irak, merefleksikan adanya pengaruh adat dari kedua negeri yang berbeda. ${ }^{28}$

${ }^{23}$ Ahmad Hasan, Pintu Ijtihad...

24 Al-Syathibî, al-Muwâfaqât fî Ushîl al-Ahkâm, Kairo: Maktabah wa Mathba'ah Muhammad Ali Shâbih, 1969-1970. H. 209-210.

25 Al-Syathibî, al-Muwâfaqât.. h. 220-2

26 Berbeda dengan fuqahâ dari kalangan Hanafiyah dan Mâlikiyah yang memegangi signifikansi sosial politik dari adat, dengan demikian menekankan kepentingan adat dalam proses penciptaan hukum mereka.

27 Ahmad Hasan, Pintu Ijtihad Sebelum..., H. 92-3.

${ }^{28}$ Muhammad Musthafâ Syalabî, Ushûl al-Fiqh al-Islâmî,... h. 322. 
Imam Ahmad bin Hanbal, sebagaimana Syafi'i tidak memperhatikan adat dalam keputusan hukumnya. Namun demikian, penerimaan Ibn Hanbal terhadap hadis dhaif ketika bersesuaian dengan adat, memberikan bukti bahwa prinsip adat tidak dikesampingkan dalam pandangan hukumnya.

Para penerus Imam Mazhab pada masing-masing mazhab, kemudian memformulasikan kaidah-kaidah yang berhubungan dengan adat secara sistematis. Misalnya, tentang macam-macam adat, syarat-syarat suatu perilaku bisa disebut adat, solusi ketika ada ta'arud antara adat dan qiyas, atau dengan keumuman lafadz dan sebagainya. Pada prinsipnya, semua mazhab fiqh sepakat memposisikan adat sebagai pertimbangan hukum, walaupun mereka berbeda dalam rinciannya.

\section{E. Macam-macam `Urf}

Pada umumnya, ulama ushûl fiqh membagi 'urf kepada tiga macam:29

1. Dari segi objeknya : 'Urf Lafdzî dan 'Urf'Amalì.

a. 'Urf Lafdzî ( العُرْنُ اللَّْْظِي ) adalah kebiasaan masyarakat dalam mempergunakan lafal/ungkapan tertentu. Sehingga makna ungkapan itulah yang dipahami dan terlintas dalam pikiran masyarakat. Misalnya, kata daging yang dipahami sebagai daging sapi, padahal kata daging meliputi seluruh daging yang ada.

b. 'Urf 'Amalî العُرْفُ العَمَلِيُ adalah kebiasaan masyarakat yang bersifat perbuatan. Misalnya, dalam jual beli tanpa adanya ijab qabul, serta kebiasaan memakai pakaian khas dalam acara-acara tertentu.

2. Dari segi cakupannya : 'Urfal-'Am dan 'Urfal-Khâsh.

a. 'Urfal-'Am: (العُرْفُ العَامُ kebiasaan yang sudah berlaku secara merata di seluruh dunia. Misalnya, penjualan parfum dalam kemasan botol yang tertutup, menganggukan kepala tatkala setuju dan menggelengkan kepala sebagai tanda menolak.

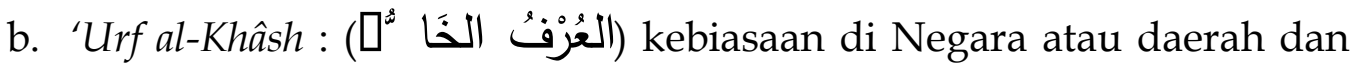
pada waktu tertentu. Contoh, penentuan masa garansi pada perdagangan suatu komoditi tertentu. Juga kebiasaan menarik garis

${ }^{29}$ Ahmad Fahmi Abu Sinnah, al-'Urf wa al-'Adah fì Ra'yî al-Fuqahâ, Mesir: Dâr Fikr, t.t. h. 16. Lihat juga Wahbah Zuhailî, Ushûl Fiqh, ... h. 829-830. Lihat juga Amir Syarifuddin, Ushûl Figh... h. 366-368.

${ }^{30}$ Dalam istilah Amir Syarifuddin, digunakan kata 'urf qaulî dan 'urf fi'lî. 
keuturunan keluarga dari pihak ibu yang berlaku khusus di daerah minangkabau.

3. Dari segi keabsahannya : 'Urf Shahîh dan 'Urf Fâsid.

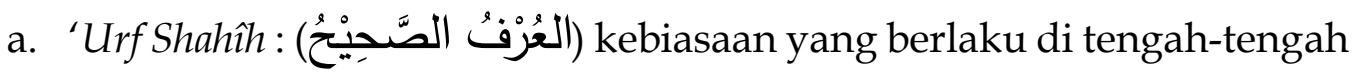
masyarakat yang tidak bertentangan dengan nash (ayat atau hadis), tidak menghilangkan kemaslahatan mereka, dan tidak pula membawa madharat. Misalnya, dalam masa pertunangan pihak lakilaki memberikan hadiah kepada pihak wanita dan hadiah ini tidak dianggap sebagai mas kawin.

b. 'Urf Fâsid: (العُرْقُ الفَاسِدِ) kebiasaan yang bertentangan dalil-dalil syara' dan kaidah-kaidah dasar yang ada dalam syara'. Misalnya, kebiasaan rentenir, risywah, korupsi, mengurangi timbangan, sex bebas, dll.

\section{F. Syarat-syarat ‘Urf}

Al-'Urf yang dipandang sama dengan al-'Adat, lebih gamblang dipahami ketika membahas tentang kaidah-kaidah fiqh, khususnya pada kaidah asas yang ke lima, yaitu al-'Adat Muhakkamah. Kaidah ini memiliki banyak kaidah cabang, yang kemudian di antaranya menentukan kriteria syarat-syarat validitas al-urf atau al-'adat.

Secara umum, kebiasaan atau tradisi yang dimaksud dalam bahasan ini, baik umum maupun khusus, merupakan dalil penguat terhadap status hukum bila terjadi persengketaan. Melalui argument al-'Adat Muhakkamah, hukum dapat ditegakkan, dengan syarat tidak bertentangan dengan syari'at, atau tidak dijumpai dalil yang secara khusus berkenaan dengannya. ${ }^{31}$

Ulama ushûl fiqh menetapkan beberapa syarat suatu 'urf sehingga dapat dijadikan dalil hukum, sebagai berikut ${ }^{32}$ :

a. 'Adat dan 'Urf bernilai mashlahat dan dapat diterima oleh akal sehat. Syarat ini telah merupakan kelaziman bagi adat dan 'urf yang shahih sebagai persyaratan untuk diterima secara umum. Misalnya, kebiasaan istri yang ditinggal mati suami, lalu dibakar hidup-hidup bersama dengan suami.

b. 'Urf itu, baik yang bersifat umum dan khusus, atau bersifat perkataan dan perbuatan, berlaku secara umum. Artinya, 'urf itu berlaku pada mayoritas

31 Abdul Azîz Muhammad bin Azzâm, Al-Qawấ'id al-Fighiyah: Dirâsah 'Amaliyah Tahliliyah Muqâranah, (Diktat Univ. al-Azhâr) Kairo: Maktabah Risâlah al-Dauliyah, 2001. H. 244 32 Ahmad Fahmi Abu Sinnah, al-'Urf wa al-'Adah... Lihat juga al-Suyûthî, al-Asybah wa alNadzâir, h. 80-88. Lihat juga Abdul Azîz Muhammad bin Azzâm, Al-Qawấ'id al-Fiqhiyah... 


\section{SALAM; Jurnal Sosial \& Budaya Syar-i}

FSH UIN Syarif Hidayatullah Jakarta

Vol. 6 No. 4 (2019)

masyarakat dan dianut oleh mayoritas masyarakat secara terus menerus di satu negara, atau di sebagian tempat. Berlaku umum dan terus menerus menjadi syarat utama.

Seperti dinyatakan dalam qaidah fiqhiyah :

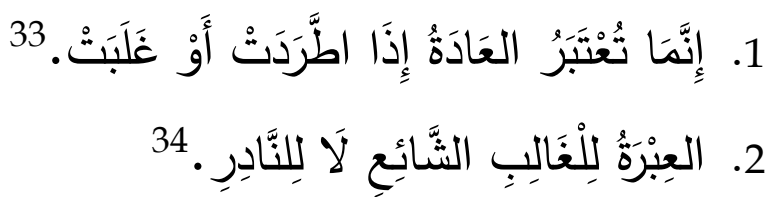

Artinya:

1. "Suatu adat dipandang sah bila berlaku terus-menerus dan digunakan secara umum".

2. "Sesuatu akan dipandang sah bila dikenal".

Dari kedua kaidah di atas dengan lugas menyatakan beberapa syarat sehingga sebuah tradisi dipandang sah, yaitu berlaku terus-menerus, diterima secara umum dan dikenal luas ${ }^{35}$. Dipertegas oleh Ibnu Najîm6, bahwa kebiasaan atau tradisi diterima bila berjalan terus-menerus dan berlaku umum. Misalnya; dalam transaksi jual beli, bila mata uang yang beredar di masyarakat bermacammacam, maka yang menjadi penentu nilai tukar adalah mata uang yang lebih dominan digunakan masyarakat. ${ }^{37}$

c. 'Urf itu telah memasyarakat ketika persoalan yang akan ditetapkan hukumnya itu muncul. Artinya, 'urf yang akan dijadikan sandaran hukum itu lebih dahulu ada sebelum kasus yang ditetapkan hukumnya. Sebagaimana dinyatakan dalam kaidah ushuliyah ;

${ }^{33}$ Al-Suyûthî, al-Asybah wa al-Nadzâir, h. 101. Lihat juga Abdul Azîz Muhammad bin Azzâm, Al-Qawấ'id al-Fiqhiyah, h. 261

34 Abdul Azîz Muhammad bin Azzâm, Al-Qawấid al-Fiqhiyah, 261.

35 Berlaku umum berarti diterima luas, dan tidak diabaikan kecuali sedikit. Para ahli fiqh berpandangan bahwa berlaku umum posisinya bagaikan syarat bagi sah tidaknya suatu

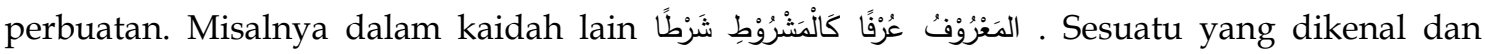
menjadi tradisi, laksana syarat pada sesuatu.

${ }^{36}$ Ibnu Najîm, al-Asybâh wa al-Nadzâir, kairo: Matba'ah al-Hadîtsah, t.t. h. 94-95.

${ }^{37}$ Ada persoalan yang muncul, bila dua kebiasaan saling berbenturan antara ada dan tidak adanya. Dua tradisi yang saling bertolak belakang ini berjalan secara seimbang, sehingga tidak ada yang lebih dominan. Misalnya, pada tradisi atas biaya pesta pernikahan. Si orang tua yang awalnya membiayai pesta nikah, memandang bahwa biaya yang dikeluarkannya adalah pinjaman yang nantinya harus dikembalikan oleh si anak. Namun, si anak mengelak, bahwa kebiasaan yang berlaku tentang siapa yang tanggungjawab atas biaya pesta adalah orang tua. Sehingga biaya yang telah keluar merupakan hadiah kepada anak. Tradisi ini disebut dengan al'Urf al-Musytarak. Oleh karena dua kebiasaan ini sama tingkatannya, tidak ada yang dimenangkan. Namun di hadapan hakim, yang didengar dan diterima pengaduannya, adalah si bapak yang disertai dengan sumpah. 


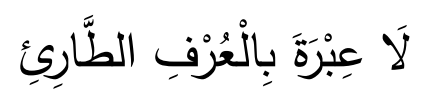

Artinya : "Urf yang datang belakangan tidak bisa dijadikan sandaran hukum terhadap kasus yang telah lama".

Kaidah ini menjadi syarat bahwa suatu kebiasaan telah memasyarakat, sehingga kaidah yang muncul hanya diberlakukan kepada tradisi tersebut, bukan tradisi lain yang datang belakangan. Oleh sebab itu, para ahli fiqh memahami tradisi yang diterima adalah kebiasaan yang terjadi pada suatu zaman tertentu dan pada wilayah tertentu pula. ${ }^{38}$ Sesuai dengan kaidah lain;

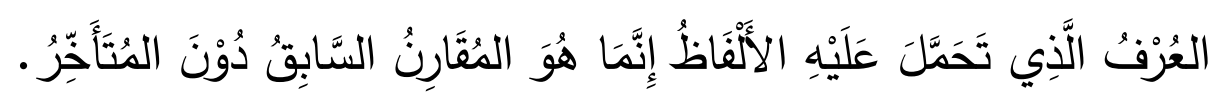

Artinya, "Sebuah lafaz (kaidah) yang terkait dengan tradisi tertentu, berlaku bagi masanya, dan tidak pada tradisi yang berlakangan".

d. 'Urf itu tidak bertentangan dengan apa yang diungkapkan secara jelas dalam suatu transaksi. Misalnya, dalam jual beli emas, pembeli yang menjual kembali barangnya dikenakan biaya Rp. 10.000 per-gramnya.

e. 'Urf itu tidak bertentangan dengan nash, sehingga menyebabkan hukum yang dikandung nash itu tidak diterapkan. 'Urf sepeti ini tidak dapat dijadikan syara' dan masuk kategori 'urf fasid.

\section{G. Kehujjahan ‘Urf}

Mazhab Hanafîyah dan Mâlikîyah berpendapat bahwa 'urf merupakan dalil syar'I dan menjadi salah satu dasar istinbath hukum serta bisa menempati posisi syarat. Sedangkan, mazhab Syafi'iyah secara dzâhir juga menggunakan 'urf ketika mendapatkan nash. ${ }^{39}$ Perbedaan antar mazhab dalam menggunakan 'urf sangat menonjol dalam hal-hal sebagai berikut:

1. Ketika terjadi ta'arudh antara 'urf dan bahasa. ${ }^{40}$

Dalam hal ini terjadi perbedaan pendapat:

a. Menurut Qâdhî Husein, hakikat penggunaan bahasa adalah beramal dengan bahasa. Bila berbenturan pengamalan bahasa itu dengan 'urf, maka didahulukan pengertian bahasa.

\footnotetext{
38 Abdul Azîz Muhammad bin Azzâm, Al-Qawấ'id al-Fiqhiyah..., h. 279.

39 Wahbah Zuhailî, Ushûl Figh, ... h. 831-832.

40 Musthafâ Dîb al-Bughâ, Atsar al-Adillah al-Mukhtalafi Fîhâ, Damaskus: Dâr al-Qalam,
} cet. 3, 1999. H. 264. Liha juga, Abdul Azîz Muhammad bin Azzâm, Al-Qawâ'id al-Fiqhiyah..., h. 271 
b. Menurut al-Baghawî, pengertian 'urflah yang lebih didahulukan dari pada makna bahasa. Sebabnya karena pengertian 'urf diperhitungkan dalam segala tindakan, apalagi dalam dalam sumpah.

c. Menurut imam Syafi'I, yang kemudian menjadi pilihan jumhur ulama bahwa mendahulukan 'urf atas pengertian bahasa, atau pengertian bahasa atas 'urf tidak dimaksudkan untuk membedakan keduanya, ini pengertian bahasa dan itu pengertian 'urf. Yang dipentingkan adalah makna yang bisa langsung ditangkap dan dipahami. Bila makna 'urf lebih dominan dalam akal pikiran, maka itu yang akan dipilih. Demikian pula sebaliknya.

Misalnya, seseorang bersumpah tidak akan tinggal di sebuah rumah. Lalu ia tinggal di sebuah kemah. Meskipun dalam kebahasaan bahwa semua tempat berteduh dan ditinggali bisa menjadi rumah, namun dalam pemahaman umum ('urf) kemah bukan rumah, sehingga orang yang bersumpah tadi tidak merasa melanggar sumpahnya. Ini bila saat bersumpah tidak berniat atas kemah sebagai bagian dari rumah.

2. Ketika terjadi ta' arud antara 'urf dan nash. ${ }^{41}$

'Urf tidak diterima bila bertentangan dengan syara'. Oleh sebab itu, kesesuaian dengan syarat menjadi syarat keabsahan 'urf. Al-Syarakhsî mengatakan bahwa semua 'urf yang bertentangan syara' tidak diterima. ${ }^{42}$ Hal ini terjadi bila pertentangan yang dimaksud pada semua sisi. Seandainya pada sebagian sisi saja, maka 'urf mentakhsisnya bila nash syara' nya bermakna umum, serta mentaqyidnya bila dalil bersifat mutlak. Dengan keputusan seperti ini, bukan berarti mengabaikan makna dalil, namun sebagai bentuk konpromi di antara keduanya. Dalil syara' dipergunakan pada wilayah khusus, sedangkan 'urf digunakan pada wilayah selainnya. Meskipun terkesan mengabaikan qiyas, tapi 'urf Nampak lebih utama dan maslahahnya lebih luas pada saat itu..$^{43}$

Pada konteks lain, pembahasan ta' arudh nash dan 'urf dipisahkan antara yang berkaitan dengan hukum dan yang tidak berkaitan dengan hukum.

a. Bila pertentangan 'urf dan syara' tidak berkaitan dengan hukum, maka 'urf lebih didahulukan. Misalnya: Jika seorang bersumpah

${ }^{41}$ Musthafâ Dîb al-Bughâ, Atsar al-Adillah... h. 268. Lihat juga

42 Syamsuddin al-Sarakhsî, al-Mabsûth, Beirut: Dâr al-Ma'rîfah, juz 10, t.t. h. 196. Abdul Azîz Muhammad bin Azzâm, Al-Qawấid al-Fiqhiyah, h. 266.

${ }^{43}$ Untuk lebih jelasnya melalui contoh berikut. Hadis Nabi melarang menjual sesuatu yang belum dimiliki secara sempurna. Ternyata dalam aqad jual beli istisna' dan jual beli salam mengindikasikan bahwa kebiasaan masyarakat dapat mentakhsis atau mentaqyid hadis Nabi. 
makan daging, tapi kemudian ia makan daging ikan, ditetapkan bahwa ia tidak melanggar sumpah. Menurut 'urf, ikan tidak termasuk daging. Namun dalam syara', ikan termasuk daging. Dalam hal ini, pengertian 'urf yang dipakai. Contoh lain, orang bersumpah tidak akan tidur di atas tiang atau pasak. Lalu ia tidur di atas gunung. Ia dipandang tidak melanggar sumpah bila tidur di atas gunung, meskipun dalam istilah al-Qur'an gunung diistilahkan pula sebagai pasak. ${ }^{4}$

b. Bila pertentangan 'urf dan syara' berkaitan dengan hukum, maka lebih didahulukan yang syara'. Misalnya, seseorang yang berwasiat kepada kerabatnya. Syara' melarang berwasiat kepada ahli waris. Jika yang berwasiat tersebut memaksudkan pula ahli waris sebagai kerabatnya, maka tidak diperbolehkan. Dengan demikian, istilah syara' yang digunakan.

3. Memposisikan 'urf sebagai syarat. ${ }^{45}$

Mazhab Hanafiyah, Mâlikiyah dan Hanbalî berpendapat bahwa adat yang sudah dikenal oleh masyarakat dalam bidang mu'amalah menempati kedudukan syarat. Dalam hal ini terdapat beberapa kaidah dalam mazhab Hanafî dengan beragam ungkapan, antara lain :

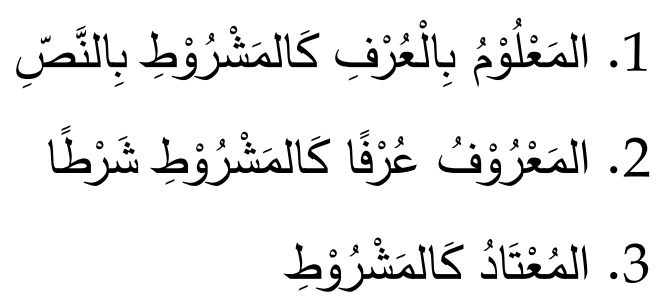

\section{H. Aplikasi ‘Urf pada Isu-Isu Kontemporer}

Dalam tataran kehidupan, banyak fenomena-fenomena baru yang muncul dalam kegiatan dan tradisi masyarakat. Misalnya, bila ditelusuri landasan hukumnya dalam syari' ah Islam, maka banyak isu-isu baru yang tidak ada nashnya dengan jelas. Diakui bahwa keabsahan produk dalam bentuk skim dalam penerapan ekonomi syariah dewasa ini berasal dari kebiasaan yang terjadi di masyarakat.

Dalam transaksi jual beli pesanan, dikenal dengan akad bai salam dan bai istisna'. Kedua akad kontrak ini bila merujuk kepada dalil hadis Nabi tentang larangan melakukan transaksi jual beli pada komoditi yang tidak dimiliki, maka seharusnya, semua bentuk transaksi yang belum dapat menujukkan wujud barang adalah tidak dibolehkan. Namua, adanya kepentingan besar dan hajat

\footnotetext{
${ }^{44}$ QS. Al-Naba' 7. Artinya, Dan gunung-gunung sebagai pasak

${ }^{45}$ Musthafâ Dîb al-Bughâ, Atsar al-Adillah... h. 269.
} 


\section{SALAM; Jurnal Sosial \& Budaya Syar-i}

FSH UIN Syarif Hidayatullah Jakarta

Vol. 6 No. 4 (2019)

hidup banyak orang terhadap akad ini serta kebiasaan yang sudah sejak dahulu dipraktekkan, maka syariah mentoleransi legalitasnya. Misalnya, memesan barang yang dipisahkan oleh jarang yang jauh, sangat memungkinkan, transaksinya deal saat ini, bahkan transferan dananya saat ini juga bisa sampai ke rekening penjual/pedagang/eksportir dan lain-lain, namun obyek barangnya bisa menyusul belakangan. Demikin pula pesanan jual beli komoditi pertanian, yang diprediksi baru akan panen beberapa bulan ke depan, atau pesana dalam beberapa kali panen, maka dimungkinkan terjadinya deal jual beli salam untuk beberapa kali panen.

Belum lagi dalam transaksi jual beli istisna' pada pesanan pembuatan kerajinan tangan, infrastruktur dan seterusnya. Pesanan ini bisa berbulan atau membutuhkan waktu lama hingga selesai dan barangnya siap untuk diserahterimakan. Adiwarman Karim membedakan sistem jual beli salam dan jual beli istisna, baik dari sisi waktu pemesanan maupun dari sisi pelunasan tagihan yang ditetapkan. ${ }^{46}$

Berikut adalah beberapa kasus yang sudah memasyarakat dan dibenarkan keabsahaannya oleh para ulama.

1. Aqad jual beli istishna' dan jual beli salam, pada barang-barang manufaktur. Hal ini bertentangan hadis Nabi yang melarang jual beli barang yang belum ada wujudnya.

2. Mazhab Mâlikiyah dan Saymsu al-Aimmah al-Hulwânî membolehkan jual beli buah di pohon yang sudah muncul sebagiannya, namun belum yang lainnya. Misalnya, membeli buah semangka, anggur dll yang baru keluar. Alasannya karena merupakan kebiasaan yang bersifat dharurat. Sebaliknya, mazhab Syafi'iyah, Hanâbilah dan Hanafiyah melarangnya.

3. Jual beli al-Mu'athâ, berupa tradisi jual beli tanpa lafadz. Seperti proses aqad di swalayan-swalayan dimana semua harga barang sudah tertera. Tinggal ambil dan bayar. Hal ini Nampak bertentangan dengan rukun sighat pada jual beli.

4. Membeli kebutuhan-kebutuhan dengan jaminan. Misalnya, adanya jaminan refarasi terhadap kerusakan barang dalam waktu tertentu. Tradisi seperti ini diperbolehkan berdasarkan kepada makna al-'urfal-'âm,

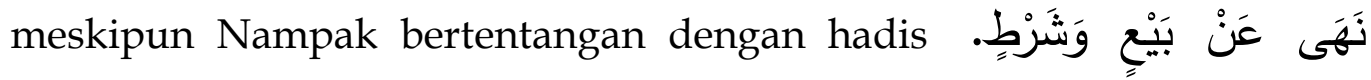
Rasulullah Saw melarang jual beli dengan syarat. Menurut Ibnu 'Abidin, pembenaran atas kasus di atas, bukan melalui makna al-'urf al-'âm, tapi melalui qiyas. Bila makna 'urf dipertentangkan dengan makna hadis, maka

${ }^{46}$ Adiwarman Karim Bank Islam, Analisis Fiqh dan Keuangan, (Jakarta: PT Raja Grafindo Persada, 2008), h. 99 
seolah-olah tidak menerima hadis. Oleh karena itu, boleh dengan qiyas, sehingga tradisi atas kasus tersebut diterima.

5. Wakaf barang-barang bergerak. Padahal syarat wakaf adalah langgeng dan menetap.

\section{Kesimpulan}

Dari penjelasan di atas, 'urf atau adat digunakan sebagai landasan dalam menetapkan hukum. Namun penerimaan ulama atas adat bukanlah sematamata ia bernama adat atau 'urf. Keduanya bukanlah dalil yang berdiri sendiri. Keduanya menjadi dalil karena ada yang mendukung, atau ada tempat sandarannya, baik dalam bentuk ijma' atau mashlahat. Adat yang berlaku secara terus menerus dikalangan umat berarti telah diterima. Bila semua ulama mengamalkannya, berarti secara tidak langsung telah terjadi ijma', walaupun dalam bentuk ijma' sukûtî.

Artinya, adat yang berlaku dan diterima oleh umat pasti membawa kemashlahatan. Dan tidak menggunakan adat, berarti menolak mashalat yang kedudukannya secara ijma' diterima dan disepakati.

Meruntut sejarah, maka kita akan melihat bahwa praktek 'urf atau adat telah diterima oleh umat islam, bahkan semenjak Rasulullah masih hidup, banyak kebiasaan yang diterima dan diadopsi karena sejalan dengan syari'ah. Masa Rasul, sahabat, imam-imam mazhab tampak menjadikan adat sebagai instrument yang cukup dominan dalam mengimplementasikan prinsip-prinsip ajaran Islam.

\section{Daftar Pustaka}

Abdul Azîz Muhammad bin Azzâm, Al-Qawầ'id al-Fiqhiyah: Dirâsah 'Amaliyah Tahliliyah Muqâranah, (Diktat Univ. al-Azhâr) Kairo: Maktabah Risâlah al-Dauliyah, 2001.

Ahmad Fahmi Abu Sinnah, al-'Urf wa al-'Adah fî Ra'yîal-Fuqahâ, Mesir: Dâr Fikr, t.t.

Ahmad Hasan, Pintu Ijtihad Sebelum Tertutup, Bandung: Pustaka 1984.

Amir Syarifuddin, Ushûl Fiqh, Jakarta: Logos Wacana Ilmu dan Pemikiran, Jilid 2, 2001.

Atabik Ali dan Ahmad Zuhdi Muhtadhar, Kamus Kontemporer : Arab Indonesia, Yogyakarta: Yayasan Ali Maksum Pondok Pesantren Krapyak. 
SALAM; Jurnal Sosial \& Budaya Syar-i

FSH UIN Syarif Hidayatullah Jakarta

Vol. 6 No. 4 (2019)

http:/ / informationmedia.wordpress.com/2009/04/15/al-\%E2\%80\%98urfsebagai-salah-satu-metode-ushul-fiqih-dalam-meng-istimbath-setiappermasalahan-dalam-kehidupan/

Ibn al-Hummâm, Syarh Fath Qadîr, Kairo : Mathba'ah Musthafâ Muhammad, Jil. $5,1356$.

Ibnu 'Abidîn dalam risalahnya II/114,

Ibnu Najîm, al-Asybâh wa al-Nadzâir, kairo: Matba'ah al-Hadîtsah, t.t. h. 94-95.

Muhammad bin Mukrâm bin Mandzûr al-Afrîqî al-Mishrî, Lisân al-'Arab, Beirut: Dar Shâdr, Jil. 3, Cet. 1.

Muhammad Hamidullah, Muslim Condust of State, Lahore: S.h. Muhammad Asyraf, 1945.

Muhammad Ibn Hasan al-Syaibânî, Siyâr al-Kabîr, Jilid 1: 194-8.

Muhammad Musthafâ Syalabî, Ushûl al-Figh al-Islâmî, Beirut: Dâr al-Nahdhah al‘Arabiyyah, Jilid I, 1986.

Musthafâ Ahmad al-Zarqâ, Al-Madkhal al-Fiqh al-'Am, juz I. Damaskus : Dâr alFikr, 1967-8.

Musthafâ Dîb al-Bughâ, Atsar al-Adillah al-Mukhtalafi Fîhâ, Damaskus: Dâr alQalam, cet. 3, 1999.

Noel J. Coulsoun, The History of Islamic Law, Edinburgh University Press, 1964.

Sarakhsî (Al), al-Mabsût, Kairo: mathba'ah al-Sa'adah, 1324-1331, jilid 12.

Sayyid Sâbiq, Fiqh Sunnah, Kairo: Dâr al-Tsaqâfah al-Ilmiyyah, Jil. 2, t.t.

Suyûthî (al), al-Asybah wa al-Nadzâir,

Syamsuddin al-Sarakhsî, al-Mabsûth, Beirut: Dâr al-Ma'rîfah, juz 10, t.t.

Syathibî (Al), al-Muwâfaqât fî̀ Ushîl al-Ahkâm, Kairo: Maktabah wa Mathba'ah Muhammad Ali Shâbih, 1969-1970.

Wahbah Zuhailî, Ushûl al-Figh al-Islâmî, Damaskus: Dâr al-Fikr,jilid 2, 1996.

Wali Allah al-Dihlâwî, Hujjatullah al-Bâlighâ, Kairo: Dâr al-Turats, Vol. 1, 1185 H. 